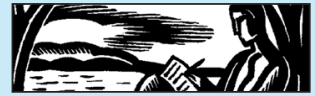

\title{
The Online Self: Memory and Forgetting in the Digital Age
}

\section{Gunnpórunn Guðmundsdóttir}

University of Iceland

\section{ABSTRACT IN ENGLISH}

Online self-expression has proliferated in the last decade or so to such an extent that more people now than ever before engage in some sort of autobiographical activity. Social networking sites are the main gateways for this expression and their framework and rules and restrictions influence the type of narrative told there. This essay examines this given framework, the role of memory and forgetting in this process and how the story is told in words and images. What is remembered and forgotten online and in turn our digital traces must influence our sense of identity. Constantly telling one's story in words and pictures online opens up new autobiographical practices, some of which in one way or another hark back to earlier practices, such as the diary or the use of the family album in autobiography, others are strictly the result of the new technology. What influence this will have in the long term is difficult to envisage, as the future use of these traces seems to be out of our control.

\section{ABSTRACT IN ICELANDIC}

Sjálfstjáning á netinu hefur aukist gríðarlega á síðasta áratug svo að nú stunda fleiri einhvers konar sjálfsævisöguleg skrif en nokkru sinni fyrr. Samfélagsmiðlar eru helsta formið fyrir pessa tjáningu og uppbygging peirra og boð og bönn hafa áhrif á frásögnina sem par birtist. Pessi grein rannsakar pessa miðla, hlutverk minnis og gleymsku í pessu ferli og hvernig frásagnir birtast í orðum og myndum. Раð sem er munað og pví sem er gleymt á netinu og par með okkar stafrænu spor hlýtur að hafa áhrif á sjálfsmynd okkar. Að segja sögu sína stöðugt í orðum og myndum á netinu opnar nýjar sjálfsævisögulegar aðferðir; sumar hverjar minna á fyrri form, eins og dagbókina eða fjölskyldualbúmið, 
aðrar eru að öllu leyti afurð nýrrar tækni. Hvaða áhrif petta mun hafa í framtíðinni er erfitt að sjá fyrir, par sem framtíðarnotkun á pessum sporum virðist ekki vera í okkar höndum.

Keywords: Online self-expression, memory, forgetting, Social Networking Sites

Social Networking Sites (SNSs) such as Facebook have now become one of the ways we tell, share, and record the story of our lives, or the stories in our lives, one of the methods we use to serve the autobiographical impulse. The proliferation and global spread of active members of these sites has taken place in a very short space of time, in just over a decade, and this swift and dramatic change in self-expression deserves our attention and calls for analysis and discussion. But the pace of these changes in the field also means that any such discussion runs the risk of quickly becoming dated and redundant [think of the fate of MySpace and the current decline of Facebook use among teenagers (Facebook 2013)]. The stories we tell of our selves and our lives are based on a complex interaction between self, identity, remembrance, forgetting, and narrative. The way we express these stories on SNSs, taking on board theories on the convergence of identity and narrative, must inevitably affect our sense of our own past, this sense which is a deciding component in our identity, our sense of self. The stories we tell of ourselves are not only the result of natural or physical processes but are always heavily circumscribed by the world around us. This includes narrative traditions, social conventions, a shared sense of what is appropriate, and the rules and rituals applied to such interaction, according to the traditions of each genre, be it autobiography, diary, letter or other similar texts, and not least the available technology. Self-expression performed online is therefore governed by a different set of rules from those operating on the blank pages of the diary, the conventions of letter writing, or within the traditional boundaries of the family album. These older traditions of self-expression and autobiographical story-telling, however, influence the type of life writing performed online in the here and now and inform many of its aspects. Thus, even if the type of mediation is recent and of our time, the stories told there are not created in a vacuum, but bear the traces of earlier practices and narrative forms. This essay addresses some of the issues I believe to be relevant to our understanding of the form these types of narratives of self-expression take, for instance the significance of the interplay between image and text, and how they can demonstrate the intervention of recent technology in our memory processes - the mediatization of our memories - not least how they shift and interrupt common patterns of forgetting. 
For our discussion on how our online activities impinge on memory and forgetting we need to look at the temporalities at play in this mode of selfexpression, although there is not space for a comprehensive analysis here. Let it suffice to say that immediacy is one of the defining features of SNSs, their 'selling point' which brings them closer to the diary than the autobiography. The sense of immediacy implied by these sites might lull us into thinking that Paul Ricoeour's ideal chronicler has been found, ${ }^{1}$ the gap between lived experience and representation has been bridged, but this is to overestimate the reality of that immediacy and underestimate the effect of mediation. SNSs cannot circumvent the problem faced by every other type of self-expression, i.e. "the fissure that opens up between experiencing an event and remembering it in representation is unavoidable," as Andreas Huyssen explains in a different context $(1995,3)$. This fissure autobiographers, biographers, diarists, and scholars of life writing have engaged with in a variety of ways through the ages. The immediate presence and ubiquity of SNSs does however add a dimension that should not be overlooked and one that autobiographies and diaries usually do not share. A status, a tweet, an image, a shared link, references an event, an experience, an opinion on a SNS, the original event itself might have been triggered by an earlier story shared on a SNS, and the way in which we experience and express our experience of these events may very well be influenced by the SNS in turn, thus the mediation and communication that takes place in this world is circular in nature. This applies to everyday events, such as a food photo posted on a site, which might encourage others to try the same recipe, posting their own photo, recipe or description in turn, setting in motion a chain reaction. This can also happen in more dramatic circumstances with political and social activism online, that can in turn generate flash-mobs, demonstrations, or even uprisings. ${ }^{2}$ In this way the things we post on SNSs, and our actions and reality, coincide and converge, creating over time with every posting an image of a self at work, at play (or at mildly drunk youtubing), while frequently diverging significantly from any sense of everyday mundane selfhood - the one that takes out the rubbish, or perhaps more appropriately does not. By 'sharing' an image of ourselves, by posting an item on a site, our presents become pasts. The presumed immediacy of such activity is of course in part illusory, but with the photography sharing site Instagram and other such sites and applications, the immediacy is of course greater than with earlier technology. Nevertheless, we turn our present into a past in the here and now, into a narrative, creating cybermemories, or at least traces of our presence in cyberspace, which no one really knows who owns or will have access to.

Thus posting texts and photographs online is one of the ways we turn the present into the past; a temporal sense of then and now has been established, the sense that by documenting an event, it becomes the past, 
no matter how recent. It is therefore relevant to discuss online self-expression in terms of memory (and thereby forgetting), despite the emphasis on SNSs on what could be termed aggressive immediacy. "Tell us what you are thinking," Facebook asks us; "Where are you now?" map apps want to know; the sites want to place us in time and space, but also insist on knowing our pasts. "Where did you go to school?" "Where were you born?" "Your profile is almost complete," Facebook points out if the user has not responded to every question. ${ }^{3}$ The emphasis is on fixing us in time and space online, and this is where corporate and commercial interests come into play, in direct opposition to the initial pull of the world online, which promised to free us from such restrictions. David Kreps shows how illusory such dreams are when in his analysis of our online self-expression he explains that each website, blogosphere, SNS, sets constraints on how we can represent ourselves:

The tools available prescribe the range of what one can be in this medium presenting for us a figure of the phenomenological constraints our identities are placed under within the socio-political context of the networked society within which such profiles are made possible. It is also clear that the romantic notions of the virtual profile gaining us freedom in the cyberspatial world from the perils and tribulations of the mundane are as illusory as the shadows of the allegorical Cave. $(2010,112)$

But what type of autobiographical narrative emerges from our (albeit limited and restricted) online behaviour and how does it relate to questions of identity? It is important to take on board Robert Cover's reminder that our identities are not static, as some would have us believe, but that its representation on SNSs displays an "ongoing reflexive performance and articulation of selfhood" (Cover 2014, 55). According to Paul John Eakin autobiographical writing is at once a manifestation of a natural process and a formative part of our selves and identities. One of the reasons for this is that we sense that our selves (and this, children can fathom from about the age of three) have a past. Our selves extend past the here and now and to cope with this we need narrative and memory. Eakin's analysis in Living Autobiographically is based on Antonio Damasio's theory of the self where our consciousness and self is divided into core consciousness and core self and extended consciousness and autobiographical self. ${ }^{4}$ The extended consciousness is created by time and our memory of time passing creates the autobiographical self, as Eakin explains: "The premise of Damasio's theory of self is "the idea that a sense of self [is] an indispensable part of the conscious mind." The body responds to its encounters with objects in its environment and it also responds to its own changing internal states" (Damasio 2000, 7; Eakin 2008, 68). As a result, Eakin 
explains: "When it comes to our identities, narrative is not merely about self, but is rather in some profound way a constituent part of self" (2). The natural, or human, process of 'living autobiographically' is in some ways challenged by the online digital world. Our profile pages can be seen to become cyber versions of ourselves, at once a product of our lived experience and an influence upon it, turning us into cyborgs without the usual prerequisite physical mechanics.

Our narratives of self are not only conditioned by biological processes, but, as mentioned above, are heavily circumscribed by cultural forms and social conventions. We need to pay attention to the form the mediation of our memories take, the framework, the maintenance, and the potential present and future audiences of the traces of these memories. Not only has online self-expression proliferated in recent years, in addition, as Nancy Thumin in her work on self-representation and digital culture points out, the two "are now inextricably linked, thus one facet of digital culture requiring theorization is precisely the ubiquitous genre of selfrepresentation" $(2012,13)$. She explains as regards the framework which governs the user's activity on Facebook: "in order to participate in online socialising here, people must represent themselves. Thus self-representation is a condition of participation in this online space. On Facebook self-representation becomes both inadvertent and banal" (138). The representation becomes banal, it forces the narrative into a certain type of framework, but its banality is not only due to the technological boundaries, but also social ones.

Not only do the sites themselves set strict boundaries for self-expression, as the user pages only allow certain type of expression in prescribed boxes, their users also develop certain codes of behaviour regarding what is appropriate, hip, or not done on these sites. In an article entitled "Bannað á Facebook," or Forbidden on Facebook, in the Icelandic newspaper Fréttablaðið in January 2014, six people (from the ages of 25-45, journalists, comedian, author, producer) were asked what they thought should not be allowed on the site. The piece is of course written with tongue firmly in cheek, but it is nevertheless an indication of how quickly social norms in the uses of new technology develop. The younger the interviewee the stricter the rules: "it is strictly forbidden to like your own status or comment," says the young comedian. "I hate people who have baby photos as their profile pictures," says the young producer (Egilsdóttir 2014, 38). The users of this fairly recent type of self-expression have evidently already formed their own strict and rather old fashioned restrictions and boundaries.

Another deciding and influencing factor in the impact of SNSs is that, as Thumin has pointed out, "commercial interests frame the 
self-representation and aesthetic, moral and political decisions are made by people other than the person representing him or herself, just as with any other kind of representation" (142). As she says, this is of course also true of other kinds of representation. For instance, life writing as a commodity is very well known, such as in the genre of the celebrity (auto)biography. But the scale of self-expression on SNSs is unprecedented both in terms of number of people using it and the frequency with which they use it, so the potential for commercial interests would appear limitless. This is of course also a privacy issue, as despite the choices of privacy settings some of the sites offer, for instance by allowing the user to choose who he shares photos and statuses with, the risk of self-exposure is still enormous. The self-expression performed in this fashion crosses the grey divide which is the division between the public and private in cyberspace, where such boundaries are blurred and constantly eroded. Autobiographical practice has of course always had to negotiate the division between the public sphere and the private, at times threatening social conventions and levels of intimacy, but again with the new technology the question has become ever more urgent. The circular movement between event, postings, images, memory, forgetting, and sense of self, is particularly prominent in this conflagration. The fear that disclosure will leave us vulnerable, or the question of what level self-exposure is appropriate in autobiographical expression, has accompanied the genre since its inception - and in the nineteenth century these issues became highly contested as Laura Marcus has demonstrated, especially with the proliferation of women's and so-called ordinary people's autobiographies (Marcus 1994, 49). The recent revelations of Edward Snowden, however, reveal the unprecedented scale of intervention in our unprecedented scale of self-expression. ${ }^{5}$ This is in addition to the social pressures on our memories already in play on such sites as mentioned above; the pressure exerted by the known quantity of readers of our self-expression. Now we have to come to terms with the fact that we have no idea whom we are telling our life stories or how, and where, and if, they will be preserved. Our lives in cyberspace are truly out of our hands, and thereby our memory traces, and so is our control over what should be forgotten or silenced.

A vital part of memory is of course forgetting, but as Viktor Mayer-Schönberger claims in his 2009 book Delete: The Virtue of Forgetting in the Digital Age: "Since the beginning of time, for us humans, forgetting has been the norm and remembering the exception. Because of digital technology and global networks, however, this balance has shifted. Today, with the help of widespread technology, forgetting has become the exception, and remembering the default" (2). The implications of this for online self-expression are by no means clear. Forgetting is an essential part of our narrative of our 
selves, without it we would not be able to tell our stories. In Andreas Hyussen's words: "Inevitably, every act of memory carries with it a dimension of betrayal, forgetting, and absence" (2003, 4). Digital technology has quite a different relationship to forgetting, and there is an interesting ongoing negotiation between our memory processes and digital memory. One of the places where this negotiation is at play is on SNSs. As Garde-Hansen, Hoskins and Reading point out: "'Social network memory' is [...] a new hybrid form of public and private memory. The instantaneity and temporality of social network environments disguise their potential as mediatized ghosts to haunt participants far beyond the life-stage of their online social networking" $(2009,6)$. Digital technology never forgets, or only due to faulty mechanics. It is however only a sum of its parts, it contains what we put in there, preserve, and arrange. Francisco Delich explains that: „Computers have memory but, as far as I can tell from my reading, they have no memories. Neither are they able to forget, since they would no longer have a raison d'être. It is a perfect memory, which can be destroyed but not selfmodified. It can be partly or wholly replaced, intentionally or not, but nothing forgotten will come back, no memory will disturb the perfect order of the system" (Delich 2004, 69). The way our digital traces are organised or archived, however, is a contentious matter, and one we have hardly any control over. It therefore seems impossible to second guess how this will influence our stories and our lives in the future.

The constant pressure in our times to preserve, publish, post, archive, and remember, ignores our need to forget. Our constant presence is required in cyberspace, disappearing is hardly an option, or rather, it involves a great deal of technological know-how, which specialised services, internet sites and self-help books offer to help one with. ${ }^{6}$ At one time or another most of us will be faced with the question of what to do with the online traces such as profiles on SNSs, blogs, email accounts, or homepages of those who pass away. Closing them all down immediately seems almost cold hearted. But then what? Should one create a memorial site, announce a person's death on their own page? How do we communicate death across the web, grief, loss, or absence. Who knows how many pages with the profiles of people who have passed away are still around on Facebook and other such SNSs. Is Facebook, along with the rest of the internet, prepared to forget? ${ }^{7}$

The intricate connection between memory and forgetting has often been compared to that of life and death, as for instance Marc Augé in Les forms de l'oubli has pointed out. Forgetting is then the end horizon for memory, but also always already there. Forgetting is a kind of death, the end of memory, the terminal point (14). Harald Weinrich claims in his seminal work on forgetting Lethe: Kunst und Kritik des Vergessens (1997; 
Lethe: The Art and Critique of Forgetting, 2004) that death not only denotes forgetting but is also a point of memory: "From time immemorial men have erected barriers against forgetting in death, so that clues suggesting remembrance of the dead are considered by specialists in prehistory and archaeology to be the surest indications of the presence of human culture" (24). Thus death and forgetting, death and remembrance are intertwined in such a way that examining what happens to the online traces of those who pass away might tell us a great deal about the workings of memory/forgetting online. It has become increasingly common to create memorial sites for the deceased, which in part solves the problem of what to do with their online lives. Such sites have a certain amount of activity, of active memory work by its members (or 'friends'), in the immediate aftermath, which then slowly decreases as time passes. What remains are memory traces that have little or no function, the pages slowly becoming sites of forgetting.

But the question I would like to address here is how will our lives in cyberspace influence our memories, our mnemonic processes and 'forgettings' (to coin a term from Julian Barnes) ${ }^{8}$ This question has arisen with every technological advance in media which has in some fashion intervened in our memory processes. The fear that technology will erode our mnemonic capabilities, will replace our 'proper' (in the sense of our own) memories with 'ersatz' memories (such as photographs) and that it will remove our ownership, our sovereign authority over the all important sentence 'I remember', has been voiced throughout our history, as evidenced by Plato's pharmakon and the many later reworkings of that term. ${ }^{9}$ Posting photos online, if we follow this line of thought, does not preserve our memories but replaces our own thoughts of the past. MayerSchönberger is on a similar path when he says:

We may stop trusting our own memory, and thus our own past, supplanting it not with an objective past but an artificial one. It's a past that is neither ours nor anybody else's; instead it is a synthetic past reconstructed from the limited information digital memory has stored about it, an utterly skewed patchwork devoid of time and open to manipulation in both what it contains, and what it doesn't. I fear that by denying ourselves our own past, we may damage our ability to judge - and more so than we think. (123)

Thus the ongoing negotiation mentioned above between our memory processes and digital memory can be highly volatile and contested. The fear of the role technology in our memory extends here to the effect it can, might, or does, have on our sense of self and identity.

Perhaps this highlights that one needs a different set of tools for approaching our digital memories. The technology might not forget, but 
the framework of the SNSs encourages a certain type of remembering, as certain things should rather be forgotten or silenced. Thus the demands and conventions of the SNSs encourage a particular type of narrative, a particular form of remembrance, a particular way of expressing our sense of self. In this way certain types of memories become part of the digital archives, others do not leave any traces there. Another obvious way in which forgetting impinges on our online lives is the self-fashioning, the image-making, at work. The glossing over, the avoidance of certain issues, the presentation of ourselves in the cyberworld, is generally not an inclusive effort, aimed to give an accurate and thorough account of our lives - there are other forces at play here.

How does all this affect or circumscribe our own online pasts and selves? We are encouraged, even required on SNSs, to tell our story in words and pictures. Users have several possibilities for posting photographs on Facebook: The profile picture and the 'cover photo,' 'selfies,' the links we post generally display an accompanying image, and older photographs, often from the family album. ${ }^{10}$ The pressure on the user to post these images manifests itself in several ways. On sites such as Facebook, if we do not use a profile picture, a ghostly blue silhouette appears instead, and such faceless pages denote the threatening presence of the internet troll, who no one wants to be associated with. Many of course try get around this pressure of self-disclosure by using an image of something completely different; a drawing maybe, an artwork, a statement of some sort, but however far removed from a conventional profile picture, it will always be read as their 'portrait', their image of themselves. ${ }^{11}$ Not posting a standard headshot therefore becomes a type of inevitable selfexpression, given the title of the page: 'my profile.' Photography is the medium which most obviously displays our presence in the world. As such and because of its intimate relationship with memory and record keeping it has become an inseparable part of autobiographical expression. SNSs not only demand a profile picture, they operate only with the constant presence of both text and image, no story told is complete without the accompanying image, courtesy of the constant presence of the camera phone. When taking a photograph on a smartphone or tablet the device immediately suggests the user shares it and gives him a variety of options, depending on the sites he has downloaded on the device. The message is clear; taking a photo is only worthwhile if it is then shared with others.

One of the photographic practices on Facebook harks back to earlier forms of remembrance, when users post old photographs they have scanned and now preserve in their digital archive. The photograph is the main medium for our past to appear on SNSs, and these photos, very often from childhood or youth, make the presence of the family album felt. 
In the postings of such photographs one can see the formation and the active participation of Maurice Halbwachs' memory groups, a technology he couldn't possibly have foreseen, proves fertile ground for such groups. Facebook makes it possible for users to establish 'groups,' either limited to certain members or open to everyone, some of which are specifically formed for the type of memory work Halbwachs describes in his theory on the workings of collective memory $(1980,25)$. For instance former students of school $\mathrm{X}$ from year $\mathrm{Y}$ form a group, often in conjunction with a reunion or a similar activity, members then post school photos and the memory work begins. Individual users also post old photographs on their own pages and what happens when those are released from the family album one might call both memory work, and evidence of the changing context of memories. The comments posted with some of those photograph reveal this. A 'friend' might say: "I remember when you looked like this," a member of the user's family might add a story or a memory to the comments, but 'friends' who have no connection to the memory can also comment and make discoveries or connections hitherto hidden or forgotten. The memory work which takes place on these sites is thus always influenced by who is allowed to participate.

When we post a photo online, 'tag' people (i.e. identify other 'friends' in the photograph, thus alerting them and their 'friends' to its existence), give it a title, we feel as if we are in control of our own self-expression, but as Joanna Garde-Hansen explains: "SNSs like Facebook can restructure, at will, how your life is organised, regardless of your objections and those of other Facebook users who create groups declaring those objections to the Facebook Company" (2009, 135). This was very much in evidence when Facebook turned 10 on 4 February 2014, marking the occasion by offering users to "make [their] own Facebook movie," which involved just such a restructuring of the user's past. When clicking on the link a short video (just over two minutes) was played entitled "A look back." It included a sentimental instrumental soundtrack and began with a sample of photographs from the year one joined with the title "Your first moments," then a couple of statuses posted in the sequence "Your most liked posts," and the sequence "Photos you shared" followed, flicking through another random sample of photographs. The first and next to last frames was a collage of photographs, in the centre the user's profile picture surrounded by other photographs shared and the last frame was the famous Facebook thumbsup, or 'like'-sign. The Facebook 'movie' is thus swathed in nostalgia with its use of appropriate music, slow moving frames and soppy titles. It taps neatly into our expectations of digital memory culture as Garde-Hansen, Hoskins and Reading see it: "A longing for memories, for capturing, storing, retrieving and ordering them: this is what digital memory culture is 
all about" $(2009,5)$. But the framing is out of the user's hands, words and images are out of context, the choice of photographs is random, and the segment turns subjects into objects, as if someone had written the user's biography. It also appeals to the user's vanity by calling the short segment a movie, and by making one look at oneself from the outside. Memories the users have shared in certain postings and the wildly eclectic choice of photographs, posted perhaps with very different intentions, transforms the past into a nostalgic turn. Surrounded by a corporate logo, it is abundantly clear who is in charge of our digital traces. This is what our past looks like as told by the Facebook Company.

The memories we share on SNSs leave traces in cyberspace. Those traces can be made use of in a variety of ways, most of which we have little or no control over. This impinges on our relationship with the past, possibly refashioning to some extent the way we remember and forget. These traces can at times be our own aide de mémoire, we can 'google' ourselves to remind ourselves when we did/said/wrote/shared this or that. But this lack of control over what will be remembered and what will be forgotten must have an effect on how we perceive our selves, not only in the past, but our sense of identity in the present. Theorists of life writing should be in a good position to add to the discourse on self-expression online; that a story of a self is always mediated comes as no surprise to us, that the medium plays a role, that there is no such thing as a 'natural' story of a life, but the sheer scale of the SNSs means we need a multi-pronged approach in our analysis of the many converging factors governing selfexpression online. ${ }^{12}$ Constantly telling our stories in words and pictures online gives rise to new interactions in memory groups, but also means that we are constantly fashioning our self image, our past, at the mercy of global businesses and our memory traces can be stored and used by governments and other such entities for some unknown future use.

\section{WORKS CITED}

Augé, Marc. Oblivion, trans. Marjolijn de Jager, Minneapolis and London: University of Minnesota Press, 2004.

Ball, James and Paul Lewis. "Twitter and the riots: How the news spread," in Reading the Riots: Investigating England's Summer of Disorder, The Guardian, 7 December 2011. http:// www.theguardian.com/uk/2011/dec/07/twitter-riots-how-news-spread.

Barnes, Julian. Nothing to be Frightened of. London: Vintage, 2009.

Cover, Robert. "Becoming and Belonging: Performativity, Subjectivity, and the Cultural Purposes of Social Networking." Identity Technologies. Eds. Anna Poletti and Julie Rak. Madson: University of Wisconsin Press, 2014, 55-69.

Damasio, Antonio. The Feeling of What Happens: The Body and Emotion in the Making of Consciousness. New York: Mariner Books, 2000. 
Delich, Francisco. "The Social Construction of Memory and Forgetting." Diogenes (201) 2004: 65-75.

Eakin, Paul John. Living Autobiographically: How We Create Identity in Narrative. Ithaca and London: Cornell University Press, 2008.

Egilsdóttir, Ugla. “Bannað á Facebook.” Fréttablaðið, 2 January 2014, p. 38.

Facebook Reports Third Quarter 2013 Result. http://investor.fb.com/releasedetail. cfm?ReleaseID=802760.

Garde-Hansen, Joanne, Andrew Hoskins and Anna Reading. "Introduction,” Save as... Digital Memories. Eds. Joanne Garde-Hansen, Andrew Hoskins and Anna Reading. New York: Palgrave Macmillan, 2009, 1-26.

Garde-Hansen, Joanna. "MyMemories?: Personal Digital Archive Fever and Facebook," Save as... Digital Memories. pp. 135-150.

Halbwachs, Maurice. On Collective Memory, trans. Francis J. Ditter and Vida Yazdi Ditter, New York: Harper and Row, 1980.

Hands, Joss. @ is for Activism. London and New York: Pluto Press, 2011.

Huyssen, Andreas. Twilight Memories: Marking Time in a Culture of Amnesia. New York and London: Routledge, 1995.

Huyssen, Andreas. Present Pasts: Urban Palimpsests and the Politics of Memory. Stanford, CA: Stanford University Press, 2003.

Kreps, David. "My Social Networking Profile: Copy, Resemblance or Simulacrum? A Poststructuralist Interpretation of Social Information Systems." European Journal of Information Systems (2010) 19, 104-115.

Marcus, Laura. Autobiographical Discourses: Theory, Criticsm, Practice. Manchester: Manchester University Press, 1994.

Massimi, Michael and Andrea Charise. "Dying, Death, and Mortality: Towards Thanatosensitivity in HCI.” CHI 2009, April 4-9, 2009: 2459-2468.

Mayer-Schönberger, Viktor. Delete: The Virtue of Forgetting in the Digital Age. Princeton: Princeton University Press, 2009.

Ricoeur, Paul. Time and Narrative, vol. 1, trans. Kathleen McLaughlin and David Pellauer, Chicago, London: University of Chicago Press, 1984.

Smith, Sidonie and Julia Watson. "Virtually Me: A Toolbox about Online Self-Presentation." Identity Technologies: Constructing the Self Online. Eds. Anna Poletti and Julie Rak. Madison: University of Wisconsin Press, 2014, 70-95.

Thumin, Nancy. Self-representation and Digital Culture. Basingstoke: Palgrave Macmillan, 2012.

Weinrich, Harald. Lethe: The Art and Critique of Forgetting, trans. Steven Rendall, Ithaca and London: Cornell University Press, 2004.

Whitehead, Anne. Memory. London and New York: Routledge, 2009.

\section{ABOUT THE AUTHOR}

Gunnpórunn Guðmundsdóttir is professor of comparative literature at the University of Iceland. She holds a PhD from the University of London and has written extensively on contemporary autobiography and life writing. Her book on the subject is Borderlines: Autobiography and Fiction in Postmodern Life Writing (2003). 


\section{NOTES}

1 "This Ideal Chronicler would be gifted with the faculty of being able to give an instantaneous transcription of whatever happens, augmenting his testimony in a purely additive and cumulative way as events are added to events. In relation to this ideal of a complete and definitive description, the historian's task would be merely to eliminate false sentences, to reestablish any upset in the order of true sentences, and to add whatever is lacking in this testimony." Ricoeur 1984, p. 145.

2 The power of the internet to generate and influence such events is of course debatable, but in terms of serving as a communicating and media tool in any such circumstances, it is without precedent. This is also a form of communications the authorities fear as Twitter and other such sites are often the first ones to be closed down or blocked by the authorities. A recent example is the protests in the early months of 2014 in Venezuela. A study by The Guardian and the London School of Economics into the 2011 London riots found that Twitter had not played a decisive role in spreading the word among rioters but had been an important tool for the media and in the clean-up that followed (Ball and Lewis, 2011). For a comprehensive analysis of the possibilities of political activism online see Joss Hands, 2011.

3 These questions and profile patterns are based on the form Facebook displays in the February 2014. As the site is constantly evolving, this might not be true at the time of publication.

4 See Damasio, 2000, i.e. pp. 174-175.

5 The leaking of the NSA files by Edward Snowden was revealed in 2013. The unfolding of the story can be seen here http://www.theguardian.com/world/the-nsa-files.

6 A myriad of sites, companies, and books claim to offer the solution to this.

7 Some important work has been done on death in the digital world, not least by Michael Massimi, on what he has termed thanatosensitivity (2009).

8 In his autobiographical work Nothing to be frightened of (2008) Julian Barnes discusses the limits of the reliability of memory: "We talk about our memories, but should perhaps talk more about our forgettings, even if that is a more difficult - or logically impossible - feat" (p. 38).

9 A useful overview of this debate can be found for instance in Anne Whithead 2009 book Memory, pp. 20-22.

10 The Facebook Company has certain restrictions on what type of photographs can be displayed, usually those that in some way infringe their rules on pornography. This was hotly debated when images of breastfeeding mothers were removed by the site. Facebook has since modified its policy and explains: "Photos that show a fully exposed breast where the child is not actively engaged in nursing do violate the Facebook Terms." https://www.facebook.com/help/340974655932193/.

11 My comments here are based on the pages of my 'friends' on Facebook and Instagram. Due to the semi-private nature of these sites, I will not be quoting verbatim from their profile pages. Another option would be to use examples of those who keep their profiles 'public', but as those sites often have a different agenda - promotional sites in one fashion or another - they would probably not be describe the behaviour of the 'average' user.

12 Sidonie Smith and Julia Watson prove this point by providing an analysis of the elements of life writing in online self-presentation in their essay "Virtually Me: A Toolbox about Online Self-Presentation", 2014, pp. 70-95. 